\title{
Sistem Pendukung Keputusan Pemilihan Lokasi Pre-Wedding di Kota Medan dengan Menggunakan Metode VIKOR dan BORDA
}

\author{
Ade Syahputra \\ Program Studi Teknik Informatika, STMIK Budi Darma, Medan, Indonesia \\ Email: adesyahputra24@gmail.com
}

\begin{abstract}
Abstrak-Sistem Pendukung Keputusan untuk pemilihan lokasi pre-wedding dengan menggunakan metode Vikor dan Borda. Telah dibuat alat untuk memilih lokasi pre-wedding dikota Medan. Kriteria yang digunakan dalam sistem pendukung keputusan pemilihan lokasi pre-wedding adalah: akses menuju lokasi, biaya, kondisi lokasi dan situasi lokasi. Mengetahui proses pemilihan lokasi pre-wedding terbaik yang masih mengalami kendala pada proses hasil pengambilan keputusan kepada calon pengantin yang ingin melakukan sesi foto pre-wedding. Pemilihan tempat Pre-Wedding sangatlah penting dilakukan karena menentukan hasil bagus atau tidaknya hasil akhir dari foto pre-wedding tersebut. Sangat banyak tempat yang sangat cocok untuk melakukan sesi foto pre-wedding contohnya dikota medan. Sistem Pendukung Keputusan dapat hadir dalam bentuk, mulai dari bentuk sederhana berupa pengelolahan data hingga bentuk aplikasi yang kompleks dan juga dapat dimanfaatkan untuk mempercepat dan meningkatkan kualitas proses pembuatan keputusan disuatu organisasi.
\end{abstract}

Kata Kunci: Sistem Pendukung Keputusan, VIKOR dan Borda, Pre-wedding.

Abstract-Decision Support System for the selection of pre-wedding locations using the Vikor and Borda methods. A tool has been made to select the pre-wedding location in the city of Medan. The criteria used in the decision support system for prewedding location selection are: access to the location, costs, location conditions and location situation. Knowing the process of selecting the best pre-wedding location that is still experiencing obstacles in the process of decision-making results for brides who want to do a pre-wedding photo session. Pre-wedding venue selection is very important because it determines the good results of the pre-wedding photo. Very many places that are very suitable for pre-wedding photo sessions for example in the city of medan. Decision Support Systems can come in forms, ranging from simple forms of data management to complex application forms and can also be used to accelerate and improve the quality of decision making processes in an organization.

Keywords: Decision Support System, VIKOR and Borda, Pre-wedding.

\section{PENDAHULUAN}

Pernikahan adalah sebuah upacara pengikatan janji nikah yang dirayakan atau dilaksanakan oleh sepasang manusia dengan maksud meresmikan ikatan perkawinan secara norma agama, norma hukum dan norma sosial. Adapun juga sebuah prosesi sebelum dilaksanakan acara perkawinan yaitu sebuah sesi foto pre-wedding. Pre-wedding dapat diartikan suatu sesi foto sebelum pernikanan. Namun seiring waktu, banyak yang akhirnya menganggap bahwa foto ini berarti foto di suatu lokasi, dengan konsep serta pakaian yang memang dipersiapkan untuk kemudian hasil foto tersebut dipajang pada acara resepsi, pada undangan dan pada suvenir pernikahan. Padahal pengertian dari kata ini sendiri sebenarnya adalah foto yang dilakukan sebelum pernikahan itu sendiri. Bisa meliputi foto pertunangan, foto acara Midodareni (dari adat budaya Jawa, malam sebelum pernikahan berlangsung). Jadi pengertian yang benar tentang foto pre-wedding adalah benar - benar foto yang dilakukan sebelum acara pernikahan, bisa berupa foto dokumentasi sebuah acara adat sebelum pernikahan, foto dokumentasi pertunangan maupun foto gaya yang selama ini banyak diketahui oleh orang dengan sebutan pre-wedding.

Mengetahui proses pemilihan lokasi pre-wedding terbaik yang masih mengalami kendala pada proses hasil pengambilan keputusan kepada calon pengantin yang ingin melakukan sesi foto pre-wedding. Pemilihan tempat Pre-Wedding sangatlah penting dilakukan karena menentukan hasil bagus atau tidaknya hasil akhir dari foto prewedding tersebut. Sangat banyak tempat yang sangat cocok untuk melakukan sesi foto pre-wedding contohnya dikota medan.

Untuk itu diperlukan adanya suatu sistem yang membantu dalam mengambil keputusan yang tepat dalam pemilihan lokasi pre-wedding tersebut dengan sistematis, Sistem Pendukung Keputusan atau Decision Support Sistem(DSS) merupakan sistem informasi interaktif yang menyediakan informasi, pemodelan, dan pemanipulasian data. Sistem ini digunakan untuk membantu pengambilan keputusan dalam situasi yang semi terstruktuk dan situasi yang tidak terstruktur, dimana tak seorang pun tahu secara pasti bagaimana keputusan yang seharusnya dibuat. Dalam proses pengambilan keputusan lokasi pre-wedding, sistem pendukung keputusan ini sangat dibutuhkan agar dapat membantu user dalam mengambil keputusan yang tepat untuk menentukan lokasi prewedding tersebut untuk lebih efesien dan tersistematis[1]-[3].

Metode yang digunakan dalam permilihan lokasi pre-wedding ini menguunakan 2 metode antara lain Vikor dan Borda. Vikor merupakan metode optimalisasi multi kriteria yang digunakan dalam sistem yang kompleks. Metode ini berfokus pada perangkingan dan memilih dari satu set alternatif, dan menentukan solusi kompromi untuk masalah kriteria yang bertentangan, yang dapat membantu para pengambil keputusan untuk mencapai keputusan akhir. Di sini, solusi kompromi adalah solusi yang layak yang paling dekat dengan ideal, dan kompromi berarti perjanjian didirikan dengan saling konsensi[4], [5]. Borda merupakan suatu model atau teknik penyelesaian masalah pengambilan keputusan di dalam suatu kelompok. Dengan borda, beberapa pendapat ataupun persepsi 
yang berbeda mengenai suatu keputusan bisa disatukan menjadi suatu keputusan kelompok/bersama. Dengan begitu, keputusan yang dihasilkan bisa diterima oleh kelompok tersebut.

Untuk mengatasi permasalahan diatas penulis membutuhkan sistem pendukung keputusan dengan menggunakan 2 metode seperti Vikor dan Borda berdasarkan kriteria yang sudah di tentukan. Metode Vikor dan Borda merupakan metode kuantitatif untuk mengidentifikasi cara kerja yang digunakan dalam pekerjaan berulang..

\section{METODE PENELITIAN}

\subsection{Sistem Pendukung Keputusan}

Sistem pendukung keputusan (Decision Support System) merupakan sistem informasi interaktif yang menyediakan informasi, pemodelan dan pemanipulasian data. Sistem itu digunakan untuk membantu pengambilan keputusan dalam situasi yang semiterstruktur dan situasi yang tidak terstruktur dimana tak seorang pun tahu secara pasti bagaimana keputusan seharusnya dibuat [6], [7]. Dengan pengertian diatas dapat disimpulkan bahwa SPK bukan merupakan alat pengambilan keputusan, melainkan merupakan sistem yang membantu pengambil keputusan dengan melengkapi mereka dengan informasi dari data yang telah diolah dengan relevan dan diperlukan untuk membuat keputusan tentang suatu masalah dengan lebih cepat dan akurat. Sehingga sistem ini tidak dimaksudkan untuk menggantikan pengambilan keputusan dalam proses pembuatan keputusan.

\subsection{Metode VIKOR}

Metode Vikor adalah salah satu metode pengambilan keputusan multi kriteria atau yang lebih dikenal dengan istilah Multi Criteria Decision Making (MCDM). MCDM digunakan untuk menyelesaikan permasalahan dengan kriteria yang bertentangan dan tidak sepadan. Metode ini berfokus pada peringkat dan pemilihan dari sekumpulan alternatif kriteria yang saling bertentangan untuk dapat mengambil keputusan untuk mencapai keputusan akhir[8] [13].

Metode ini mengambil keputusan dengan solusi mendekati ideal dan setiap alternatif dievaluasi berdasarkan semua kriteria yang telah ditetapkan. Vikor melakukan perangkingan terhadap alternatif dan menentukan solusi yang mendekati solusi kompromi ideal. Metode Vikor sangat berguna pada situasi dimana pengambil keputusan tidak memiliki kemampuan untuk menentukan pilihan pada saat desain sebuah sistem dimulai[14]-[20]. Langkah-langkah perhitungan dengan metode Vikor sebagai berikut :

1. Melakukan normalisasi menggunakan rumus sebagai berikut:

$$
R_{i j}=\left(\frac{x_{j}^{+}-x_{i j}}{x_{j}^{+}-x_{j}^{-}}\right)
$$

Dimana $R_{i j}$ dan $X_{i j}(i=1,2,3, \ldots, m$ dan $j=1,2,3, \ldots, n)$ adalah elemen dari matriks pengambilan keputusan (alternatif i terhadap kriteria $\mathrm{j}$ ) dan $\mathrm{X}_{\mathrm{j}}^{+}$adalah elemen terbaik dari kriteria $\mathrm{j}, \mathrm{X}_{\mathrm{j}}^{-}$adalah elemen terburuk dari kriteria j.

2. Menghitung nilai $\mathrm{S}$ dan $\mathrm{R}$ menggunakan rumus sebagai berikut:

$$
\begin{aligned}
& \mathrm{S}_{\mathrm{i}}=\sum_{j=1}^{n} \mathrm{w}_{\mathrm{j}}\left(\frac{\mathrm{x}_{\mathrm{j}}^{+}-\mathrm{x}_{\mathrm{ij}}}{\mathrm{x}_{\mathrm{j}}^{+}-\mathrm{x}_{\mathrm{j}}^{-}}\right) \mathrm{dan} \\
& \mathrm{R}_{\mathrm{i}}=\operatorname{Max} j\left[\mathrm{w}_{\mathrm{j}}\left(\frac{\mathrm{x}_{\mathrm{j}}^{+}-\mathrm{x}_{\mathrm{ij}}}{\mathrm{x}_{\mathrm{j}}^{+}-\mathrm{x}_{\mathrm{j}}^{-}}\right)\right] \\
& \text {Dimana } \mathrm{W}_{\mathrm{j}} \text { adalah bobot dari tiap kriteria } \mathrm{j}
\end{aligned}
$$

3. Menentukan nilai indeks

$$
\mathrm{Q}_{\mathrm{i}}=\left[\frac{S_{i}-S^{+}}{S^{+}-S^{-}}\right] \mathrm{v}+\left[\frac{R_{i}-R^{+}}{R^{+}-R^{-}}\right](1-\mathrm{v})
$$

Dimana $\mathrm{S}^{-}=\min \mathrm{S}_{\mathrm{i}}, \mathrm{S}^{+}=\max \mathrm{S}_{\mathrm{i}}$ dan $\mathrm{R}^{-}=\min \mathrm{R}_{\mathrm{i}}, \mathrm{R}^{+}=\max \mathrm{R}_{\mathrm{i}}$ dan $\mathrm{v}=0,5$.

4. Hasil perangkingan merupakan hasil pengurutan dari $\mathrm{S}, \mathrm{R}$ dan $\mathrm{Q}$

5. Solusi alternatif peringkat terbaik berdasarkan dengan nilai Q minimum menjadi peringkat terbaik dengan syarat:

$$
\begin{aligned}
& \mathrm{Q}\left(\mathrm{A}^{(2)}\right)-\mathrm{Q}\left(\mathrm{A}^{(1)}\right) \geq \mathrm{DQ} \\
& \text { Dimana: } \\
& \mathrm{A}^{(2)}=\text { alternatif dengan urutan kedua pada perangkingan } \mathrm{Q} \text { dan } \\
& \mathrm{A}^{(1)}=\text { alternatif dengan urutan terbaik pada perangkingan } \mathrm{Q} \text { sedangkan } \\
& \mathrm{DQ}=1 \text { - }(\mathrm{m}-1) \text {, dimana m merupakan jumlah alernatif. } \\
& \text { Alternatif } \mathrm{A}^{(1)} \text { harus berada pada rangking terbaik pada } \mathrm{S} \text { dan } \mathrm{R}
\end{aligned}
$$

\subsection{Metode BORDA}

Prinsip metode borda adalah memberikan peringkat pada alternatif-alternatif yang ada. Alternatif yang mempunyai peringkat teratas diberinilai tertinggi, demikian seterusnya secara menurun diberikan nilai lebih rendah untuk peringkat dibawahnya sampai pada peringkat terendah diberinilai 0 atau 1. Ide dari metode Borda adalah mengharuskan para pemilih memberikan rangking kepada tiap kandidat, serta memberikan nilai untuk tiap-tiap 
peringkat misalnya, yaitu peringkat pertama diberikan nilai 2, peringkat kedua diberikan nilai 1 , dan peringkat ketiga diberikan nilai 0 . Pengertian lain borda merupakan suatu metode voting yang digunakan pada pengambilan keputusan kelompok untuk pemilihan single winner ataupun multiple winner. Borda menentukan pemenang dengan memberikan sejumlah nilai tertentu untuk masing-masing alternatif. Selanjutnya pemenang akan ditentukan oleh banyaknya jumlah nilai yang dikumpulkan alternatif. Pada sistem pendukung keputusan kelompok salah satu masalah yang sering dihadapi adalah bagaimana mengagregasikan opini-opini dari para pengambil keputusan untuk menghasilkan suatu keputusan yang tepat.

\subsection{Pre-Wedding}

Kata Foto Pre-Wedding berasal dari bahasa Inggris yang jika diartikan dalam bahasa Indonesia akan berarti foto sebelum pernikahan. Namun seiring waktu, banyak yang akhirnya menganggap bahwa foto ini berarti foto di suatu lokasi, dengan konsep serta pakaian yang memang dipersiapkan untuk kemudian hasil foto tersebut dipajang pada acara resepsi, pada undangan dan pada suvenir pernikahan. Padahal pengertian dari kata ini sendiri sebenarnya adalah foto yang dilakukan sebelum pernikahan itu sendiri. Bisa meliputi foto pertunangan, foto acara Midodareni (dari adat budaya Jawa, malam sebelum pernikahan berlangsung). Jadi pengertian yang betul tentang Foto prewedding adalah benar- benar foto yang dilakukan sebelum acara pernikahan, bisa berupa foto dokumentasi sebuah acara adat sebelum pernikahan, foto dokumentasi pertunangan maupun foto gaya yang selama ini banyak diketahui oleh orang dengan sebutan pre-wedding.

\section{HASIL DAN PEMBAHASAN}

Sistem pendukung keputusan pemilihan lokasi Pre-Wedding merupakan suatu sistem yang dibuat untuk memilih lokasi pre-wedding untuk para calon pasangan pengantin yang sesuai dengan kriteria yang telah ditetapkan Dalam sistem pemilihan lokasi pre-wedding ini dapat membantu calon pasangan pengantin sesuai dengan kriteria yang sudah ditentukan. Analisa masalah dilakukan untuk mendapatkan gambaran secara lengkap mengenai permasalahan yang ada.

Kegiatan pemilihan lokasi pre-wedding merupakan suatu kegiatan yang dilakukan oleh para calon pengantin. Namun pemilihan yang tepat sesuai dengan kriteria yang terbaik dan bukan hal mudah. Banyaknya yang dipilih bisa jadi membuat bingung dalam pemilihan. Jenis-jenis kriteria yang sudah ditentukan untuk sebagai tujuan akhir penentu. Kriteria yang sudah ditentukan yaitu; biaya, akses, situasi dan kondisi.

Dalam pemilihan lokasi pre-wedding yang ada dikota medan beberapa hal yang menjadi permasalahan antara lain yaitu penyeleksian secara objektif dan subjektif. Subjektif yaitu penyeleksian yang didasari dimana seseorang akan berpikir secara relatif dengan hasil yang menduga, dan menggunakan perasaan, walaupun berdasarkan kriteria yang ada, sedangkan objektif yaitu penyeleksian yang didasari sikap yang harus menjunjung tinggi seseorang yang berdasarkan pandangan terhadap suatu masalah. Oleh karena itu, dibutuhkan suatu sistem pendukung keputusan dimana penyeleksian yang dilakukan secara subjektif dan objektif. Maka dari itu, dalam pemilihan lokasi pre-wedding dikota Medan mengunakan metode VIKOR dan Borda.

Metode VIKOR merupakan penentuan ranking dari sampel-sampel yang sudah ada dengan melihat hasil dari nilai utilitas, regres dan jarak solusi sebagai alternatif terbaik dari setiap sampel dengan pembobotan kriteria dari metode Analysis Hierarchy Proses. Metode yang digunakan dalam penyelesaian masalah adalah sistem penunjang keputusan kelompok yang dilakukan dengan perkalian dari nilai referensinya dengan bobot dari ranking.

Metode borda adalah peringkatan pada tiap alternatif-alternatif yang ada. Alternatif yang mempunyai peringkat teratasd yang benilai tinggi, yang seharusnya secara menurun diberikan nilai lebih rendah untuk peringkat dibawahnya sampai pada peringkat terendah yang bernilai 0 atau 1 . Borda menentukan pemenang yang mempuanyai point terbanyak.

Adapun data Lokasi Pre-wedding yang akan diuji adalah sebagai berikut:

Tabel 1. Data Lokasi Pre-Wedding

\begin{tabular}{|c|c|c|c|c|c|}
\hline No & Nama Lokasi & Biaya & $\begin{array}{c}\text { Akses Menuju } \\
\text { lokasi }\end{array}$ & $\begin{array}{l}\text { Situasi } \\
\text { Lokasi }\end{array}$ & Kondisi Lokasi \\
\hline 1 & Kampung Ladang & Rp 1.500 .000 & Sedang & Aman & Sepi \\
\hline 2 & Taman Cadika & Rp 150.000 & Mudah & Sedang & Sedang \\
\hline 3 & Mercy Barn / Medan Resort City & Rp 100.000 & Mudah & Aman & Sedang \\
\hline 4 & The Le Hu Garden & Rp 250.000 & Mudah & Aman & Sedang \\
\hline 5 & $\mathrm{~T}$ Garden & Rp 350.000 & Mudah & Aman & Sedang \\
\hline 6 & Istana Maimoon & Rp 100.000 & Mudah & Sedang & Aman \\
\hline 7 & Royal Sumatera & Rp 100.000 & Mudah & Aman & Sepi \\
\hline 8 & Kenanga Garden & Rp 350.000 & Mudah & Aman & Sedang \\
\hline 9 & Lapangan Merdeka & Rp 80.000 & Mudah & Sedang & Ramai \\
\hline 10 & Lapangan Benteng & Rp 100.000 & Mudah & Aman & Ramai \\
\hline
\end{tabular}




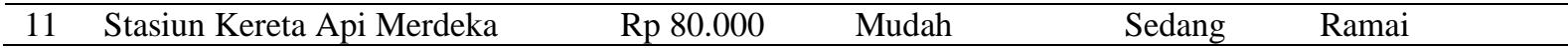

\subsection{Penerapan dengan Metode Vikor}

Dalam pemilihan lokasi pre-wedding dikota Medan, sesuai dengan metode Vise Kriterijumska Optimizacija Kompromisno Resenje (VIKOR) dan Borda yang merupakan penyelesaian masalah dengan diperlukan adanya kriteria-kriteria dan bobot untuk melakukan proses perhitungannya sehingga akan didapat alternatif terbaik, dalam penelitian ini alternatif yang dimaksud penulis adalah pemilihan lokasi pre-wedding yang akan dilakukan dikota Medan.

Penetuan kriterian dan bobot, dalam tahapan ini dibutuhkan kriteria yang akan dijadikan bahan perhitungan pada proses pemilihan lokasi pre-wedding. Hal tersebut dimaksud untuk memilih lokasi pre-wedding mana yang akan terpilih sebagai lokasi pre-wedding yang akan dilakukan dikota Medan. Adapun kreteria yang dibutuhkan sebagai bahan pertimbangan oleh calon pasangan dapat dilihat pada tabel 2. berikut ini.

Tabel 2. Tabel Kriteria

\begin{tabular}{cc}
\hline Kriteria & Keterangan \\
\hline C1 & Biaya \\
C2 & Akses Menuju Lokasi \\
C3 & Situasi \\
C4 & Kondisi \\
\hline
\end{tabular}

Dalam menentukan pemilihan lokasi pre-wedding dikota Medan menggunakan metode Vlse Kriterijumska Optimizacija Kompromisno Resenje (VIKOR) dan Borda, maka terlebih dahulu ditentukan bobot (w) awal dari setiap kriteria. Pada bobot terdiri dari enam bilangan Fuzzy, yaitu Sangat Buruk (SB1), Buruk (B1), Cukup (C), Baik (B2), dan Sangat Baik (SB2) seperti terlihat pada table di bawah ini:

Tabel 3. Bobot

\begin{tabular}{lc}
\hline \multicolumn{1}{c}{ Bilangan Fuzzy } & Nilai \\
\hline Sangat Buruk $\left(\mathrm{SB}_{1}\right)$ & 10 \\
Buruk (B1) & 15 \\
Cukup (C) & 20 \\
Baik (B2) & 25 \\
Sangat Baik $\left(\mathrm{SB}_{2}\right)$ & 30 \\
\hline
\end{tabular}

Pada pembobotan untuk tiap-tiap kriteria ditentukan dari tingkat kepentingan dari masing-masing kriteria. Tingkat kepentingan tertinggi terdapat pada kriteria biaya dan akses menuju lokasi, kemudian kriteria untuk situasi serta kondisi memiliki tingkat kepentingan kedua. Berdasarkan dari nilai bobot terhadap kepentingan dari masingmasing kriteria maka bobot awal untuk masing-masing kriteria (C1-C4) dari setiap alternatif dapat dilihat pada tabel berikut.

Tabel 4. Menentukan Kriteria Biaya

\begin{tabular}{ccc}
\hline Biaya & Bilangan Fuzzy & Nilai \\
\hline Rp 10.000 - Rp 300.000 & Sangat baik & 30 \\
$\operatorname{Rp~350.000-Rp~600.000~}$ & Baik & 25 \\
$\operatorname{Rp} 650.000-\operatorname{Rp} 900.000$ & Cukup & 20 \\
$\operatorname{Rp} 950.000-\operatorname{Rp~} 1.200 .000$ & Buruk & 15 \\
$\operatorname{Rp~} 1.250 .000-\operatorname{Rp~} 1.500 .000$ & Sangat Buruk & 10 \\
\hline
\end{tabular}

Tabel 5. Menentukan Kriteria Akses Menuju Lokasi

\begin{tabular}{ccc}
\hline Akses Menuju Lokasi & Bilangan Fuzzy & Nilai \\
\hline Mudah & Sangat baik & 30 \\
Sedang & Baik & 25 \\
Sulit & Cukup & 20 \\
\hline
\end{tabular}

Tabel 6. Menentukan Kriteria Situasi Lokasi

\begin{tabular}{ccc}
\hline Situasi Lokasi & Bilangan Fuzzy & Nilai \\
\hline Aman & Sangat Baik & 30 \\
Sedang & Baik & 25 \\
Tidak Aman & Cukup & 20 \\
\hline
\end{tabular}

Tabel 7. Menentukan Kriteria Kondisi Lokasi

$\begin{array}{lll}\text { Kondisi Lokasi } & \text { Bilangan Fuzzy } & \text { Nilai }\end{array}$




\begin{tabular}{ccc}
\hline Sepi & Sangat Baik & 30 \\
Sedang & Baik & 25 \\
Ramai & Cukup & 20 \\
\hline
\end{tabular}

Tabel 8. Bobot w

\begin{tabular}{cc}
\hline Keterangan & Bobot (w) \\
\hline Biaya Lokasi & $0.40 \%$ \\
Akses Menuju Lokasi & $0.30 \%$ \\
Situasi Lokasi & $0.20 \%$ \\
Kondisi & $0.10 \%$ \\
\hline
\end{tabular}

Tabel 9. Rating Kecocokan Dari Setiap Alternatif Pada Setiap Kriteria

\begin{tabular}{ccccc}
\hline \multirow{2}{*}{ Alternatif } & \multicolumn{4}{c}{ Kriteria } \\
\cline { 2 - 5 } & C1 & C2 & C3 & C4 \\
\hline A1 & 10 & 45 & 50 & 90 \\
A2 & 30 & 47 & 45 & 68 \\
A3 & 30 & 50 & 47 & 66 \\
A4 & 30 & 47 & 50 & 55 \\
A5 & 25 & 48 & 50 & 67 \\
A6 & 30 & 48 & 44 & 30 \\
A7 & 30 & 50 & 50 & 10 \\
A8 & 25 & 49 & 48 & 10 \\
A9 & 30 & 47 & 48 & 40 \\
A10 & 30 & 50 & 48 & 50 \\
A11 & 30 & 50 & 43 & 10 \\
MAX & 30 & 50 & 50 & 90 \\
MIN & 10 & 45 & 43 & 10 \\
\hline
\end{tabular}

Langkah-langkah menghitung nilai kriteria dengan metode Vikor:

1. Melakukan normalisasi data

Dari tabel nilai masing-masing kriteria akan dilakukan normalisasi data, yaitu:

a. Kriteria untuk $\mathrm{C} 1$

$$
\begin{aligned}
& \mathrm{R}(\mathrm{A} 1), \mathrm{C} 1=\frac{(30-10)}{(30-10)}=\frac{20}{20}=1 \\
& \mathrm{R}(\mathrm{A} 2), \mathrm{C} 1=\frac{(30-30)}{(30-30)}=\frac{0}{20}=0
\end{aligned}
$$

Dengan langkah-langkah perhitungan diatas maka didapatkan data normalisasi semua sampel, berikut disajikan tabel data normalisasi semua sampel (normalisasi matriks).

Tabel 10. Normalisasi Matriks

\begin{tabular}{ccccc}
\hline \multirow{2}{*}{ Alternatif } & \multicolumn{4}{c}{ Kriteria } \\
\cline { 2 - 5 } & C1 & C2 & C3 & C4 \\
\hline A1 & 1 & 1 & 0 & 0 \\
A2 & 0 & 0,6 & 0,7 & 0,275 \\
A3 & 0 & 0 & 0,4 & 0,3 \\
A4 & 0 & 0,6 & 0 & 0,4375 \\
A5 & 0,25 & 0,4 & 0 & 0,2875 \\
A6 & 0 & 0,4 & 0,858 & 0,75 \\
A7 & 0 & 0 & 0 & 0,875 \\
A8 & 0,25 & 0,2 & 0,29 & 1 \\
A9 & 0 & 0,6 & 0,29 & 0,625 \\
A10 & 0 & 0 & 0,29 & 0,5 \\
A11 & 0 & 0 & 1 & 1 \\
\hline
\end{tabular}

Tabel 11. Hasil Normalisasi x Bobot

\begin{tabular}{ccccc}
\hline \multirow{2}{*}{ Alternatif } & \multicolumn{5}{c}{ Kriteria } \\
\cline { 2 - 5 } & C1 & C2 & C3 & C4 \\
\hline A1 & 0,40 & 0,30 & 0 & 0 \\
A2 & 0 & 0,18 & 0 & 0,0275 \\
A3 & 0 & 0 & 0,08 & 0,03 \\
A4 & 0 & 0,18 & 0 & 0,04373 \\
\hline
\end{tabular}




\begin{tabular}{ccccc}
\hline \multirow{2}{*}{ Alternatif } & \multicolumn{5}{c}{ Kriteria } \\
\cline { 2 - 5 } & C1 & C2 & C3 & C4 \\
\hline A5 & 0,1 & 0,12 & 0 & 0,02875 \\
A6 & 0 & 0,12 & 0,1716 & 0,07 \\
A7 & 0 & 0 & 0 & 0,1 \\
A8 & 0,1 & 0,06 & 0,058 & 0,1 \\
A9 & 0 & 0,18 & 0,058 & 0,0625 \\
A10 & 0 & 0 & 0,058 & 0,05 \\
A11 & 0 & 0 & 0,20 & 0,1 \\
\hline
\end{tabular}

2. Menghitung Nilai $\mathrm{S}$ dan $\mathrm{R}$

Rumus $\mathrm{S}_{\mathrm{i}}=\sum_{j=1}^{n} w j x(R i j)$

Nilai S didapatkan dari penjumlahan hasil perkalian bobot kriteria dengan data pada setiap sampel.

Berikut ini disajikan perhitungan nilai $\mathrm{S}$.

$$
\begin{aligned}
\mathrm{S}(\mathrm{A} 1) & =0,40+0,30+0+0 \\
& =0,7 \\
\mathrm{~S}(\mathrm{~A} 2) & =0+0,18+0,14+0,0275 \\
& =0,3475
\end{aligned}
$$

Rumus Ri= Max j[wj x Rij]

Nilai $\mathbf{R}$ adalah nilai terbesar dari perkalian bobot kriteria dengan data normalisasi dari setiap sampel. Berikut nilai $\mathbf{R}$ untuk semua sampel adalah:

Tabel 12. Nilai $S$ dan $R$

\begin{tabular}{ccc}
\hline Alternatif & $\mathrm{S}$ & $\mathrm{R}$ \\
\hline A1 & 0,7 & 0,40 \\
A2 & 0,3475 & 0,0275 \\
A3 & 0,11 & 0,08 \\
A4 & 0,2237 & 0,18 \\
A5 & 0,2488 & 0,12 \\
A6 & 0,3616 & 0,12 \\
A7 & 0,1 & 0,1 \\
A8 & 0,345 & 0,1 \\
A9 & 0,3005 & 0,18 \\
A10 & 0,108 & 0,058 \\
A11 & 0,3 & 0,20 \\
Max & $\mathbf{0 , 7}$ & $\mathbf{0 , 4 0}$ \\
Min & $\mathbf{0 , 1}$ & $\mathbf{0 , 0 2 7 5}$ \\
\hline
\end{tabular}

3. Menghitung Indeks Vikor

Rumus $\mathrm{Q}_{\mathrm{i}}=\left[\frac{S_{i}-S^{+}}{S^{-}-S^{+}}\right] \mathrm{v}+\left[\frac{R_{i}-R^{+}}{R^{-}-R^{+}}\right](1-\mathrm{v})$

Alternatif dengan nilai $Q$ terkecil merupakan alternatif terbaik.

berikut disajikan perhitungan nilai indeks Vikor $(\mathrm{Q})$ :

$$
\begin{aligned}
\mathrm{Q}(\mathrm{A1}) & =\left[\frac{0,7-0,1}{0,7-0,1}\right] * 0,5+\left[\frac{0,40-0,0275}{0,40-0,0275}\right] *(1-0,5) \\
& =\left[\frac{0,6}{0,6}\right] * 0,5+\left[\frac{0,3725}{0,3725}\right] *(0,5) \\
& =(1 * 0,5)+(1 * 0,5) \\
& =0,5+0,5=1
\end{aligned}
$$

Dari perhitungan indeks Vikor (Q) diatas maka diperoleh tabel peringkat indeks Vikor.

Tabel 13. Indeks Vikor

\begin{tabular}{ccc}
\hline Alternatif & Nilai Q & Peringkat \\
\hline A10 & 0,0475 & 1 \\
A3 & 0,0789 & 2 \\
A7 & 0,1106 & 3 \\
A2 & 0,2062 & 4 \\
A5 & 0,2625 & 5 \\
\hline
\end{tabular}

Dari tabel diatas diperoleh data bahwa alternatif (A10, A3, A7, A2, A5) yaitu Lapangan Benteng, Mercy Barn / Medan Resort City, Royal Smatera, Taman Cadika, T Garden yang memiliki nilai indeks Vikor terkecil yaitu $((\mathbf{0 , 0 4 7 5}),(\mathbf{0 , 0 7 8 9}),(\mathbf{0 , 0 1 1 0 6}),(\mathbf{0 , 2 0 6 2}),(\mathbf{0 , 2 6 2 5}))$, sehingga dalam penelitian ini beberapa lokasi dalam penyelesian metode vikor dan terpilih sebagai lokasi pre-wedding dikota Medan. 


\subsection{Penerapan dengan Metode Borda}

Perhitungan metode borda untuk menentukan keputusan penyeleksian calon Lokasi Pre-wedding adalah sebagai berikut;

1. Dari hasil perhitungan referensi dari masing-masing pengambil keputusan, hitung jumlah nilai referensi yang menyatakan rangking untuk tiap alternative. Tuliskan angka nilai preferensinya pada kolom satu untuk peringkat 1 , dua untuk peringkat 2 , dan seterusnnya

2. Kalikan angka pada kolom peringkat dengan bobot dibawahnya kemudian tambahkan dengan hasil perkalian pada jenis yang sama kemudian isikan hasil pada kolom rangking.

3. Jumlah hasil rangking, sehingga membentuk poin borda.

4. Untuk mencari nilai borda, bagi poin borda tiap alternative dengan jumlah poin borda

Tabel 14. Pemilihan

\begin{tabular}{lllllllll}
\hline Alternatif & A10 & A3 & A7 & A2 & A5 & A8 & A4 & A6 \\
\hline Fotografer & 1 & 2 & 3 & 2 & 1 & 2 & 1 & 3 \\
Calon Pengantin Pria & 2 & 1 & 4 & 2 & 4 & 1 & 4 & 4 \\
Calon Pengantin Wanita & 4 & 3 & 1 & 2 & 3 & 1 & 4 & 2 \\
Editor & 3 & 2 & 1 & 3 & 2 & 3 & 2 & 1 \\
\hline
\end{tabular}

Tabel 15. Bobot Rangking Borda

\begin{tabular}{cc}
\hline Rangking & Bobot \\
\hline 1 & 0.40 \\
2 & 0.30 \\
3 & 0.20 \\
4 & 0.20 \\
\hline
\end{tabular}

Tabel 17. Perhitungan Borda

\begin{tabular}{|c|c|c|c|c|c|c|}
\hline \multirow{2}{*}{ Alternatif } & \multicolumn{4}{|c|}{ Peringkat } & \multirow[t]{2}{*}{ Poit Borda } & \multirow[t]{2}{*}{ Ranking } \\
\hline & 1 & 2 & 3 & 4 & & \\
\hline A10 & 1 & 1 & 1 & 1 & 1 & 6 \\
\hline A3 & 1 & 2 & 1 & - & 1,2 & 2 \\
\hline A7 & 2 & - & 1 & 1 & 1,1 & 3 \\
\hline A2 & - & 3 & 1 & - & 1 & 4 \\
\hline A5 & 1 & 1 & 1 & 1 & 1 & 5 \\
\hline A8 & 2 & 1 & 1 & - & 1,3 & 1 \\
\hline A4 & 1 & 1 & - & 2 & 0,9 & 7 \\
\hline A6 & 1 & - & 2 & 1 & 0,9 & 8 \\
\hline Bobot Ranking & 0,40 & 0,30 & 0,20 & 0,10 & 8,5 & \\
\hline
\end{tabular}

Tabel 18. Perhitungan Hasil Borda

\begin{tabular}{ccc}
\hline Alternatif & Hasil Borda & Peringkat \\
\hline A8 & 1,3 & 1 \\
A3 & 1,2 & 2 \\
A7 & 1,1 & 3 \\
A4 & 1,1 & 4 \\
A5 & 1 & 5 \\
\hline
\end{tabular}

Berdasarkan hasil pada table 4.18, maka didapatkan urutan rekomendasi alternatif keputusan kelompok pengambilan keputusan yaitu $1=\mathrm{A} 8 ; 2=\mathrm{A} 3 ; 3 \mathrm{~A} 7 ; 4=\mathrm{A} 4 ; 5=\mathrm{A} 5$. Hasil dari perhitungan borda merupakan rekomendasi keputusan kelompok. Berdasarkan 5 rekomendasi alternatif, maka akan diambil 3 alternatif sebagai lokasi terpilih untuk pre-wedding.

\section{KESIMPULAN}

Berdasarkan hasil dari penelitian yang telah penulis lakukan, maka dapat diambil beberapa kesimpulan yaitu :

1. Sistem pendukung keputusan ini dapat membantu proses pemilihan lokasi pre-wedding berdasarkan penjumlahan terbobot dan kriteria-kriteria yang telah ditentukan.

2. Sistem pendukung keputusan ini dapat diterapkan dengan metode Vlse Kriterijumska Optimizacija I Kompromisno Resenje (VIKOR) dan metode BORDA dalam pemilihan lokasi pre-wedding dikota Medan.

3. Sistem pendukung keputusan ini dapat dirancang untuk menentukan pemilihan lokasi pre-wedding dikota Medan dengan menggunakan Visual Basic.Net 2008 dan Database Mysql. 


\section{REFERENCES}

[1] S. Kusumadewi, S. Hartati, A. Harjoko, and Retantyo Wardoyo, Fuzzy Multi-Attribute Decision Making (FUZZY MADM). 2006.

[2] Kusrini, Konsep dan Aplikasi Sistem Pendukung Keputusan. 2007.

[3] Efraim Turban and Jay E. Aronson, Decision Support System and Intelligent Systems. 2001.

[4] G.-H. Tzeng and J.-J. Huang, Multiple Attribute Decision Making Method And Applications. CRC Press, 2011.

[5] M. Yazdani and F. R. Graeml, "VIKOR and its Applications," Int. J. Strateg. Decis. Sci., vol. 5, no. 2, pp. 56-83, Apr. 2014.

[6] T. Limbong et al., Sistem Pendukung Keputusan: Metode \& Implementasi. Medan: Yayasan Kita Menulis, 2020.

[7] D. Nofriansyah, Konsep Data Mining Vs Sistem Pendukung Keputusan. 2015.

[8] B. J. Hutapea, M. A. Hasmi, and A. Karim, "Sistem Pendukung Keputusan Penentuan Jenis Kulit Terbaik Untuk Pembuatan Sepatu Dengan Menggunakan Metode VIKOR," J. Ris. Komput., vol. 5, no. 1, pp. 6-12, 2018.

[9] A. A. Trisnani, D. U. Anwar, W. Ramadhani, M. M. Manurung, and A. P. U. Siahaan, "Sistem Pendukung Keputusan Pemilihan Karyawan Berprestasi Menerapkan Metode Vise Kriterijumska Optimizajica I Kompromisno Resenje (VIKOR)," JURIKOM (Jurnal Ris. Komputer), vol. 5, no. 2, pp. 85-90, Apr. 2018

[10] Y. J. B. Parrangan et al., "The Implementation of VIKOR Method to Improve the Effectiveness of Sidi Learning Graduation," Int. J. Eng. Technol., vol. 7, pp. 264-267, 2018.

[11] T. Imandasari and A. P. Windarto, "Penerapan Metode VIKOR Pada Pemilihan Popok Bayi Berdasarkan Jenis Kulit," pp. 215-220, 2018.

[12] A. Siregar, P. Ginting, M. Mesran, and L. T. Sianturi, "Implementasi Metode Vikor Dalam Pemilihan Supplier Bahan Baku," KOMIK (Konferensi Nas. Teknol. Inf. dan Komputer), vol. I, pp. 132-138, 2017.

[13] M. Sianturi, S. Wulan, Suginam, Rohminatin, and Mesran, "Implementasi Metode VIKOR Untuk Menentukan Bahan Kulit Terbaik Dalam Pembuatan Ikat Pinggang," J. Ris. Komput., vol. 5, no. 1, pp. 56-60, 2018.

[14] W. Jingzhu and L. Xiangyi, "The multiple attribute decision-making VIKOR method and its application," in 2008 International Conference on Wireless Communications, Networking and Mobile Computing, WiCOM 2008, 2008.

[15] Mesran, K. Ulfa, D. P. Utomo, and I. R. Nasution, "Penerapan Metode VlseKriterijumska Optimizacija I Kompromisno Resenje ( Vikor ) Dalam Pengangkatan Guru," Algoritm. J. Ilmu Komput. dan Inform., vol. 4, no. 1, pp. 265-271, 2020.

[16] M. F. El-santawy, "A VIKOR Method for Solving Personnel Training," Int. J. Comput. Sci., vol. 1, no. 2, pp. 9-12, 2012.

[17] D. Siregar et al., "Multi-Attribute Decision Making with VIKOR Method for Any Purpose Decision," in 1st International Conference on Green and Sustainable Computing (ICoGeS) 2017, 2018, vol. 1019, no. 1.

[18] I. Wijaya and Mesran, "Penerapan Metode AHP dan VIKOR Dalam Pemilihan Karyawan Berprestasi," in Seminar Nasional Teknologi Komputer \& Sains (SAINTEKS), 2019, pp. 301-309.

[19] A. Siregar, P. Ginting, Mesran, and L. T. Sianturi, "Implementasi Metode Vikor Dalam Pemilihan Supplier Bahan Baku," KOMIK (Konferensi Nas. Teknol. Inf. dan Komputer), vol. I, pp. 132-138, 2017.

[20] M. Mesran et al., "The VIKOR Method to Support the Effectiveness of Decisions in Determining Work Incentive Recipients," J. Phys. Conf. Ser., vol. 1175, p. 012043, 2019. 